\title{
ANALISIS HUBUNGAN PELAYANAN DENGAN KEPUASAN PELANGGAN PADA BENGKEL CANDERA MOTOR DI KAUR UTARA KABUPATEN KAUR
}

\author{
Mitior \\ Karona Cahya Susena \\ Program Studi Manajemen \\ Fakultas Ekonomi Universitas Dehasen Bengkulu
}

\begin{abstract}
ABSTRAK
Mitior, Karona Cahya Susena; Analisis Hubungan Pelayanan Dengan Kepuasan Pelanggan Pada Bengkel Candera Motor Di Kaur Utara Kabupaten Kaur. Penelitian ini bertujuan untuk menganalisis hubungan pelayanan dengan kepuasan pelanggan pada bengkel Candera Motor di Kaur Utara Kabupaten Kaur.. Metode analisis yang digunakan adalah analisis korelasi Spearman Rank dan pengujian kebenaran data dengan uji t. Hasil penelitian korelasi rank spearman memiliki korelasi sebesar 0,701 artinya antara pelayanan dengan kepuasan pelanggan bengkel Candera Motor di Kaur Kabupaten Kaur memiliki korelasi yang kuat, ini berarti bahwa semakin tinggi pelayanan yang diberikan oleh bengkel Candera Motor Kaur maka akan semakin tinggi pula tingkat kepuasan dari para pelanggan bengkel Candera Motor Kaur. Hasil pengujian hipotesis membuktikan bahwa $t_{\text {hitung }}$ lebih besar dari $t_{\text {tabel }}(7,482>1,672)$. Dengan demikian hasil hipotesis adalah $\mathrm{HO}$ ditolak dan $\mathrm{Ha}$ diterima. artinya pelayanan mempunyai hubungan yang signifikan dengan kepuasan pelanggan bengkel Candera Motor di Kaur Utara Kabupaten Kaur.
\end{abstract}

\section{ABSTRACT}

Mitior, Karona Cahya Susena; An Analysis of the relationship between Services and the Customer Satisfaction At Motor Candera repair shop In Kaur regency. This research aimed to analyze the relationship between Services and the Customer Satisfaction At Motor Candera repair shop In Kaur regency. It used Spearman Rank and $t$ test as the data analysis method. The result of the research showed that it has a correlation of 0,701 in spearman rank. It means that there is a high correlation between the services and the customer satisfaction in Candera Motor. The higher the service provided will increasingly the levels of satisfaction of the customer. The Hypothesis testing results showed that tcount is greater than ttable $(7,482>1,672)$. Thus the hypothesis $H O$ is rejected and the $\mathrm{Ha}$ are received. It means that the services has a significant relationship with the customer satisfaction at Candera Motor repair shop in Kaur regency.

\section{Kata kunci: Pelayanan, Kepuasan Pelanggan \\ PENDAHULUAN}

Persaingan yang semakin ketat terjadi di dalam dunia otomotif khususnya produk sepeda motor karena produk ini merupakan alat transportasi darat yang paling dominan banyak dimiliki dan dibutuhkan oleh masyarakat. Memang tidak mudah menjadi yang terbaik, selain harus menyediakan kualitas terbaik juga ada faktor pola perilaku konsumen yang tidak mudah ditebak, apalagi di 
Indonesia yang terdiri dari banyak pulau, sehingga memiliki ragam pola perilaku yang berbeda pula.

Kesuksesan dalam persaingan akan dapat dipenuhi apabila perusahaan bisa menciptakan dan mempertahankan pelanggan (Tjiptono, 2006:19). Perhatian perusahaan dalam hal layanan dan kepuasan pelanggan akan memberikan nilai lebih pada kualitas layanan dan kualitas kepuasan pelanggan. Kualitas layanan dan kualitas kepuasan pelanggan dapat dijadikan perusahaan sebagai instrumen untuk menanggulangi tingkat persaingan yang semakin ketat. Pada pasar persaingan sempurna, pelanggan mempunyai berbagai pilihan alternatif layanan dan informasiyang memadai, kepuasan pelanggan merupakan salah satu kunci dari tingkat permintaan layanan tersebut. Perhatian perusahaan pada kebutuhan pelanggan secara cermat diperlukan guna memenuhi keinginan dan meningkatkan kepuasan atas layanan yang diberikan.

Kepuasan pelanggan didapat dari terpenuhnya harapan pelanggan terhadap suatu jasa yang dikonsumsinya. Menurut Kotler (2009:49) kepuasan pelanggan adalah perasaan senang atau kecewa seseorang yang disebabkan oleh kinerja atau hasil suatu produk yang dirasakan, dibandingkan dengan harapannya. Apabila jasa yang didapat pelanggan lebih kecil dari apa yang diharapkan pelanggan maka pelanggan akan menjadi tidak puas, tidak tertarik dan kecewa kepada penyedia jasa yang bersangkutan. Sedangkan apabila jasa yang dirasa oleh pelanggan melebihi apa yang diharapkan maka pelanggan akan merasa puas. Tingkat kepuasan pelanggan dapat diperoleh setelah terjadinya tahap pembelian dan pemakaian.

Menurut Tjiptono (2006:65) kepuasan atau ketidakpuasan pelanggan adalah respon pelanggan terhadap evaluasi ketidakpuasan (disconfirmation) yang dirasakan antara harapan sebelumnya atau harapan kinerja lainnya dan kinerja aktual produk yang dirasakan setelah memakainya. Evaluasi proses terjadi setelah tahap pembelian dan pemakaian. Kepuasan pelanggan akan tercapai jika suatu layanan dinilai memuaskan dan dapat memenuhi kebutuhan pelanggan serta apa yang dirasakan pelanggan sesuai dengan harapan yang diinginkan. Perusahaan perlu mengukur tingkat kepuasan pelanggan untuk dapat menyediakan layanan yang lebih baik, efektif, dan efisien. Suatu layanan tidak dapat dikatakan efektif dan efisien apabila tidak disertai dengan kepuasanpelanggan.

Kepuasan pelanggan menjadi landasan sistim layanan yang tanggap terhadap kebutuhan pelanggan, meminimalkan biaya dan waktu, serta memaksimalkan layanan terhadap dampak populasi sasaran. Parasuraman (2001:26) mengemukakan konsep kualitas layanan yang berkaitan dengan kepuasan ditentukan oleh lima unsur yang biasa dikenal dengan istilah kualitas layanan "RATER" (responsiveness, assurance, tangible, empathy dan reliability)

Kunci sukses agar pelanggan memilih jasa layanan bengkel adalah dengan memberikan kepuasan kepada pelanggan. Kepuasan tersebut dapat dicapai melalui pemberian layanan dan dukungan yang optimal kepada pelanggan. Pemberian layanan dan dukungan yang optimal itu dapat diberikan kepada pelanggan melalui pemberian layanan yang cepat sehingga pelanggan tidak perlu menunggu lama dibengkel, keramahan karyawan dalam melayani pelanggan, dan pemberian saran- saran perawatan mesin kepada pelanggan.

Dalam penelitian ini, bengkel Candera Motor di Kabupaten Kaur Utara dijadikan sebagai tempat penelitian. Bengkel Candera Motor mempunyai peluang dan tantangan seperti bengkel-bengkel pada umumnya. Pelanggan akan membandingkan layanan dan dukungan yang diberikan Bengkel Candera Motor dengan layanan dan dukungan yang mereka harapkan. Jika pelanggan merasa puas, maka pelanggan akan kembali lagi ke Bengkel Candera Motor dan menjadi pelanggan yang setia serta akan menceritakan pengalaman tersebut kepada orang lain, sehingga jumlah pelanggan Bengkel Candera Motor akan bertambah. 
Tetapi jika pelanggan merasa tidak puas, maka pelanggan akan mengeluhkan ketidakpuasannya tersebut kepada pihak bengkel Candera Motor.

Ketidakpuasan pelanggan atau keluhan pelanggan adalah suatu resiko pekerjaan yang tidak perlu dicemaskan, justru dengan adanya keluhan dan kekecewaan pelanggan, pihak perusahaan bisa lebih banyak belajar mengenal karakter pelanggan. Dengan kondisi tersebut, perusahaan dapat mencari solusi dalam mengatasi ketidakpuasan pelanggan.

\section{TINJAUAN LITERATUR}

\section{Jasa}

Menurut Lovelock dan Wright (2005:5) tedapat dua pendekatan untuk mendefenisikan jasa, pendekatan yang pertama jasa adalah "tindakan atau kinerja yang menciptakan manfaat bagi pelanggan dengan mewujudkan perubahan yang diinginkan dalam diri atau atas nama penerima" dan pendekatan yang kedua jasa adalah " kegiatan ekonomi yang menciptakan dan memberikan manfaat bagi pelanggan pada waktu dan tempat tertentu, sebagai hasil dari tindakan mewujudkan perubahan yang diinginkan dalam diri atau atas nama penerima jasa tersebut.

Menurut Kotler (2009:111), jasa adalah setiap tindakan atau kinerja yang dapat ditawarkan satu pihak kepada pihak lain, yang pada dasarnya tidak berwujud dan tidak mengakibatkan kepemilikan sesuatu. Produksinya mungkin saja terkait atau mungkin juga tidak terkait dengan produk fisik. Definisi lain jasa adalah setiap tindakan atau perbuatan yang dapat ditawarkan oleh suatu pihak kepada pihak lain, yang pada dasarnya bersifat tidak berwujud fisik dan tidak menghasilkan kepemilikan sesuatu (Tjiptono, 2006:3).

Jasa sering dipandang sebagai suatu fenomena yang rumit. Kata jasa itu sendiri mempunyai banyak arti, dari mulai layanan personal sampai jasa sebagai suatu produk. Sejauh ini sudah banyak pakar pemasaran jasa yang telah berusaha mendefinisikan jasa. Sementara perusahaan yang memberikan operasi jasa adalah mereka yang memberikan konsumen produk jasa baik yang berwujud atau tidak. Di dalam jasa selalu ada aspek interaksi antara pihak konsumen dan pemberi jasa, meskipun pihak-pihak yang terlibat tidak selalu menyadari.

Menurut Lovelock dan Wright (2005 : 96) menyatakan kualitas jasa didasarkan pada evaluasi kognitif jangka panjang terhadap penyerahan jasa perusahaan. Jadi, kualitas jasa ialah tingkat keunggulan yang diharapkan dan pengendalian atas tingkat keunggulan tersebut untuk memenuhi keinginan pelanggan.

\section{Pemasaran Jasa}

Pemasaran jasa merupakan proses sosial dimana dengan proses itu, individu dan kelompok mendapatkan apa yang mereka butuhkan dan inginkan dengan mempertukarkan jasa yang bernilai dengan pihak lain, yang mana pada dasarnya tidak berwujud dan tidak mengakibatkan kepemilikan sesuatu.

Pemasaran pada produk barang berbeda dengan pemasaran untuk produk jasa (Lupiyoadi, 2008:70). Hal ini terkait dengan perbedaan karakteristik jasa dan barang. Pemasaran produk barang mencakup 4P, yaitu: product, price, promotion dan place. Sedangkan untuk jasa, keempat unsur tersebut ditambah tiga lagi, yaitu: people, process, dan customer service. Ketiga hal tersebut terkait dengan sifat jasa di mana produksi/operasi hingga konsumsi merupakan suatu rangkaian yang tidak dapat dipisahkan dalam mengikutsertakan konsumen dan pemberi jasa secara langsung. 
Dengan demikian maka elemen pemasaran jasa terdiri dari 7 hal, yaitu (Lupiyoadi, 2008:70):

a. Product, jasa seperti apa yang ingin ditawarkan

b. Price, bagaimana strategi penentuan harga

c. Promotion, bagaimana promosi yang harus dilakukan

d. Place, Bagaimana system penghantar (Delivering System) yang akan ditetapkan

e. People, Tipe kualitas dan kuantitas orang yang akan terlibat dalam pemberian jasa

f. Proccess, Bagaimana proses dalam operasi jasa tersebut

g. Customer Service, Tingkat service (Service Level) yang bagaimana yang akan diberikan kepada konsumen .

\section{Karakteristik-karakteristik Jasa}

Dalam buku Kotler \& Armstrong (2008:292-293), jasa memiliki karakteristikkarakteristik khusus yang harus dipertimbangkan oleh perusahaan ketika merancang program pemasaran. Karakteristik-karakteristik khusus jasa yaitu :

1.

Jasa tidak berwujud

Jasa tidak berwujud berarti bahwa jasa tidak dapt dilihat, dirasakan, diraba, didengar, atau dibaui sebelum jasa itu dibeli.

2. Jasa tak terpisahkan

Jasa tak terpisahkan berarti bahwa jasa tidak dapat dipisahkan dari penyedianya, tanpa mempedulikan apakah penyedia jasa itu orang atau mesin.

3.

Variabilitas jasa

Variabilitas jasa berarti bahwa kualitas jasa bisa sangat beragam, tergantung pada siapa yang menyediakan jasa itu dan kapan, di mana, dan bagaimana jasa itu disediakan.

4.

Jasa dapat musnah

Jasa dapat musnah berarti bahwa jasa tidak disimpan untuk dijual atau digunakan beberapa saat kemudian.

Berdasarkan keempat karesteristik tersebut, menurut Kotler (2007:72) "the offer" atau penawaran jasa dapat dibagi menjadi empat kategori, yaitu :

1. Barang berwujud murni (a pure tangible goods)

Disini hanya terdiri dari barang berwujud seperti sabun, pasta gigi.Tidak ada jasa yang menyertai produk tersebut.

2. Barang berwujud yang disertai jasa (a tangible goods with accompanying service) Terdiri dari barang-barang berwujud yang disertai dengan satu atau lebih jasa untuk mempertinggi daya tarik pelanggan. Contohnya: produsen mobil tidak hanya menjual mobil saja, melainkan juga kualitas dan pelayanan kepada pelangganya.

3. Jasa utama yang disertai barang dan jasa tambahan (a major service with accompanying minor goods and service)

Terdiri dari jasa utama dan jasa tambahan dan atau barang perengkap. Contoh: penumpang pesawat terbang membeli jasa transportasi. Mereka sampai ditujuan tanpa sesuatu hai berwujud yang . memperlihatkan pengeluaran mereka. Namun perjalanan tersebut, meliputi barang-barang berwujud, seperti makanan dan minuman, potongan tiket dan majalah penerbangan.

4. Jasa Murni (a pure service)

Hanya terdiri dari jasa, contohnya adalah: jasa menjaga bayi, psikotrapi, dan lain sebagainnya.

\section{Konsep Kualitas layanan}


Konsep kualitas layanan pada dasarnya memberikan persepsi secara konkrit mengenai kualitas suatu layanan. Konsep kualitas layanan ini merupakan suatu revolusi secara menyeluruh, permanen dalam mengubah cara pandang manusia dalam menjalankan atau mengupayakan usaha-usahanya yang berkaitan dengan proses dinamis, berlangsung, terus menerus di dalam memenuhi harapan, keinginan dan kebutuhan. Hal ini sesuai dengan teori "Quality" yang dikemukakan oleh Marcel (2003:192) bahwa keberhasilan suatu tindakan jasa ditentukan oleh kualitas. Kualitas merupakan apresiasi tertinggi dari tindakan pelayanan.

Stemvelt (2004:210) menyatakan bahwa konsep kualitas layanan adalah suatu persepsi tentang revolusi kualitas secara menyeluruh yang terpikirkan dan menjadi suatu gagasan yang harus dirumuskan (formulasi) agar penerapannya (implementasi) dapat diuji kembali (evaluasi), untuk menjadi suatu proses yang dinamis, berlangsung, terus menerus dalam memenuhi kepuasan pelanggan. Apabila jasa yang diterima atau dirasakan sesuai dengan yang diharapkan, maka kualitas jasa dipersepsikan baik dan memuaskan

Yong dan Loh (2003:146) memberikan suatu pengertian bahwa konsep kualitas layanan adalah suatu kecocokan untuk penggunaan (fitness for yours) yang bertujuan untuk menemukan suatu pemikiran yang jelas dari proses pemikiran yang melahirkan adanya suatu pemahaman yang tidak sulit untuk dipahami, karena tujuannya jelas dan prosesnya merupakan continue quality improvement (proses yang berkelanjutan).

Menurut Tjiptono (2006:59), kualitas Iayanan adalah tingkat keunggulan yang diharapkan dan pengendalian atas tingkat keunggulan tersebut untuk memenuhi keinginan pelanggan. Dengan kata lain ada dua faktor utama mempengaruhi kualitas jasa, yaitu expected service dan perceived service atau kualitas jasa yang diharapkan dan kualitas jasa yang diterima atau dirasakan.

Kesenjangan pelayanan adalah hal yang penting, karena hal itulah yang merupakan penilaian konsumen secara keseluruhan terhadap apa yang diharapkan dibandingkan dengan apa yang diterima. Tujuan utama dalam meningkatkan kualitas pelayanan adalah memperkecil kesenjangan ini sedapat mungkin. Berikut adalah jenis-jenis kesenjangan yang dapat timbul dalam kualitas pelayanan (Lovelock \& Wright, 2005 : 96-98) :

1. Kesenjangan Pengetahuan

Perbedaan anatara apa yang diyakini perusahaan akan diharapkan konsumen dan kebutuhan dan harapan konsumen yang sesungguhnya.

2. Kesenjangan Standar

Perbedaan antara persepsi manajemen terhadap harapan konsumen dan standar kualitas yang ditetapkan untuk penyerahan pelayanan.

3. Kesenjangan Penyerahan

Perbedaan antara standar penyerahan yang ditentukan dan kinerja perusahaan yang sesungguhnya.

4. Kesenjangan Komunikasi Internal

Perbedaan antara apa yang dianggap oleh iklan dan tenaga penjual perusahaan tersebut sebagai fitur produk, kinerja dan tingkat kualtas pelayanan dan apa yang benar-benar diinginkan oleh perusahaan.

5. Kesenjangan Persepsi

Perbedaan persepsi antara apa yang benar-benar diserahkan dan apa yang dianggap konsumen telah mereka terima (karena mereka tidak dapat menilai kualitas pelayanan secara akurat).

6. Kesenjangan Interpretasi 
Perbedaan antara apa yang sesungguhnya dijanjikan perusahaan dalam upaya-upaya komunikasinya dan apa yang konsumen pikir telah dijanjikan dalam komunikasi tersebut.

7. Kesenjangan Jasa

Perbedaan antara apa yang diharapkan konsumen akan mereka terima dan persepsi mereka terhadap pelayanan yang benar-benar diserahkan.

\section{Unsur-unsur Kualitas Layanan}

Menurut Tjiptono (2006:70) elemen kualitas jasa (layanan) terdiri dari:

\section{Daya tanggap (Responsiveness)}

Menurut Tjiptono (2006:70), daya tanggap (responsiveness) merupakan keinginan para staf untuk membantu para konsumen dan memberikan layanan dengan tanggap. Daya tanggap dapat berarti tingkat respon, inisiatif, dan kesigapan karyawan dalam membantu pelanggan dan memberikan layanan yang cepat, yang meliputi kecepatan karyawan dalam menangani transaksi dan kesigapan serta kesabaran penanganan dalam proses konsumsi jasa. Para anggota perusahaan harus memperhatikan janji spesifik kepada pelanggan. Unsur lain yang juga penting dalam elemen cepat tanggap ini adalah anggota perusahaan selalu siap membantu pelanggan. Apa pun posisi seseorang di perusahaan hendaknya selalu memperhatikan pelanggan yang menghubungi perusahaan.

Margaretha (2003:163) kualitas layanan daya tanggap adalah suatu bentuk pelayanan dalam memberikan penjelasan, agar orang yang diberi pelayanan tanggap dan menanggapi pelayanan yang diterima, sehingga diperlukan adanya unsur kualitas layanan daya tanggap sebagai berikut:

a.

Memberikan penjelasan secara bijaksana sesuai dengan bentuk-bentuk pelayanan yang dihadapinya. Penjelasan bijaksana tersebut mengantar individu yang mendapat pelayanan mampu mengerti dan menyetujui segala bentuk pelayanan yang diterima.

b.

Memberikan penjelasan yang mendetail yaitu bentuk penjelasan yang substantif dengan persoalan pelayanan yang dihadapi, yang

c. bersifat jelas, transparan, singkat dan dapat dipertanggung- jawabkan.

Memberikan pembinaan atas bentuk-bentuk pelayanan yang dianggap masih kurang atau belum sesuai dengan syarat-syarat atau prosedur pelayanan yang ditunjukkan.

d.

Mengarahkan setiap bentuk pelayanan dari individu yang dilayani untuk menyiapkan, melaksanakan dan mengikuti berbagai ketentuan pelayanan yang harus dipenuhi.

e.

Membujuk orang yang dilayani apabila menghadapi suatu permasalahan yang dianggap bertentangan, berlawanan atau tidak sesuai dengan prosedur dan ketentuan yang berlaku.

Uraian-uraian di atas menjadi suatu interpretasi yang banyak dikembangkan dalam suatu organisasi kerja yang memberikan kualitas layanan yang sesuai dengan daya tanggap atas berbagai pelayanan yang ditunjukkan. Inti dari pelayanan daya tanggap dalam suatu organisasi berupa pemberian berbagai penjelasan dengan bijaksana, mendetail, membina, mengarahkan dan membujuk. Apabila hal ini dapat diimplementasikan dengan baik, dengan sendirinya kualitas layanan daya tanggap akan menjadi cermin prestasi kerja pegawai yang ditunjukkan dalam pelayanannya.

\section{Jaminan (Assurance)}


Menurut Tjiptono (2006:70), jaminan (assurance) merupakan pengetahuan, kemampuan, kesopanan, dan sifat dapat dipercaya yang dimiliki para staf; bebas dari bahaya, risiko atau keragu-raguan. Pada saat persaingan sangat kompetitif, anggota perusahaan harus tampil lebih kompeten, artinya memiliki pengetahuan dan keahlian di bidang masing- masing. IBM sangat menekankan faktor-faktor tersebut kepada para teknisi yang menangani pemasangan dan layanan purna jual. Faktor security, yaitu memberikan rasa aman dan terjamin kepada pelanggan merupakan hal yang juga penting.

Margaretha (2003:215) suatu organisasi kerja sangat memerlukan adanya kepercayaan yang diyakini sesuai dengan kenyataan bahwa organisasi tersebut mampu memberikan kualitas layanan yang dapat dijamin sesuai dengan:

a. Mampu memberikan kepuasan dalam pelayanan yaitu setiap pegawai akan memberikan pelayanan yang cepat, tepat, mudah, lancar dan berkualitas, dan hal tersebut menjadi bentuk konkrit yang memuaskan orang yang mendapat pelayanan.

b.

Mampu menunjukkan komitmen kerja yang tinggi sesuai dengan bentuk-bentuk integritas kerja, etos kerja dan budaya kerja yang sesuai dengan aplikasi dari visi, misi suatu organisasi dalam memberikan pelayanan.

c.

Mampu memberikan kepastian atas pelayanan sesuai dengan perilaku yang ditunjukkan, agar orang yang mendapat pelayanan yakin sesuai dengan perilaku yang dilihatnya.

Uraian ini menjadi suatu penilaian bagi suatu organisasi dalam menunjukkan kualitas layanan asuransi (meyakinkan) kepada setiap orang yang diberi pelayanan sesuai dengan bentuk-bentuk kepuasan pelayanan yang dapat diberikan, memberikan pelayanan yang sesuai dengan komitmen kerja yang ditunjukkan dengan perilaku yang menarik, meyakinkan dan dapat dipercaya, sehingga segala bentuk kualitas layanan yang ditunjukkan dapat dipercaya dan menjadi aktualisasi pencerminan prestasi kerja yang dapat dicapai atas pelayanan kerja.

\section{Bukti Fisik (Tangible)}

Menurut Tjiptono (2006:70), bukti fisik (tangible) meliputi fasilitas fisik, perlengkapan, pegawai, dan sarana komunikasi. Hal ini bisa berarti penampilan fasilitas fisik, seperti gedung dan ruangan front office, tersedianya tempat parkir, keberhasilan, kerapian dan kenyamanan ruangan, kelengkapan peralatan komunikasi, dan penampilan karyawan. Prasarana yang berkaitan dengan layanan pelanggan juga harus diperhatikan oleh manajemen perusahaan

Arisutha (2005:49) menyatakan prestasi kerja yang ditunjukkan oleh individu sumberdaya manusia, menjadi penilaian dalam mengaplikasikan aktivitas kerjanya yang dapat dinilai dari bentuk pelayanan fisik yang ditunjukkan. Biasanya bentuk pelayanan fisik tersebut berupa kemampuan menggunakan dan memanfaatkan segala fasilitas alat dan perlengkapan di dalam memberikan pelayanan, sesuai dengan kemampuan penguasaan teknologi yang ditunjukkan secara fisik dan bentuk tampilan dari pemberi pelayanan sesuai dengan perilaku yang ditunjukkan. Dalam banyak organisasi, kualitas layanan fisik terkadang menjadi hal penting dan utama, karena orang yang mendapat pelayanan dapat menilai dan merasakan kondisi fisik yang dilihat secara langsung dari pemberi pelayanan baik menggunakan, mengoperasikan dan menyikapi kondisi fisik suatu pelayanan.

Selanjutnya, tinjauan Margaretha (2003:65) yang melihat dinamika dunia kerja dewasa ini yang mengedepankan pemenuhan kebutuhan pelayanan masyarakat maka, identifikasi kualitas layanan fisik mempunyai peranan penting dalam memperlihatkan kondisi-kondisi fisik pelayanan tersebut. Identifikasi 
kualitas layanan fisik (tangible) dapat tercermin dari aplikasi lingkungan kerja berupa:

a. Kemampuan menunjukkan prestasi kerja pelayanan dalam menggunakan alat dan perlengkapan kerja secara efisien dan efektif.

b. Kemampuan menunjukkan penguasaan teknologi dalam berbagai akses data dan inventarisasi otomasi kerja sesuai dengan dinamika dan perkembangan dunia kerja yang dihadapinya.

c.

Kemampuan menunjukkan integritas diri sesuai dengan penampilan yang menunjukkan kecakapan, kewibawaan dan dedikasi kerja.

Uraian ini secara umum memberikan suatu indikator yang jelas bahwa kualitas layanan sangat ditentukan menurut kondisi fisik pelayanan, yang inti pelayanannya yaitu kemampuan dalam menggunakan alat dan perlengkapan kerja yang dapat dilihat secara fisik, mampu menunjukkan kemampuan secara fisik dalam berbagai penguasaan teknologi kerja dan menunjukkan penampilan yang sesuai dengan kecakapan, kewibawaan dan dedikasi kerja.

\section{Empati (Empathy)}

Menurut Tjiptono (2006:70), empati (empathy) merupakan kemudahan dalam melakukan hubungan, komunikasi yang baik, perhatian pribadi, dan memahami kebutuhan para konsumen. Setiap anggota perusahaan hendaknya dapat mengelola waktu agar mudah dihubungi, baik melalui telepon ataupun bertemu langsung. Dering telepon usahakan maksimal tiga kali, lalu segera dijawab. Ingat, waktu yang dimiliki pelanggan sangat terbatas sehingga tidak mungkin menunggu terlalu lama. Usahakan pula untuk melakukan komunikasi individu agar hubungan dengan pelanggan lebih akrab.

Berarti empati dalam suatu organisasi kerja menjadi sangat penting dalam memberikan suatu kualitas layanan sesuai prestasi kerja yang ditunjukkan oleh seorang pegawai. Empati tersebut mempunyai inti yaitu mampu memahami orang yang dilayani dengan penuh perhatian, keseriusan, simpatik, pengertian dan adanya keterlibatan dalam berbagai permasalahan yang dihadapi orang yang dilayani. Margaretha (2003:78) bahwa suatu bentuk kualitas layanan dari empati orang-orang pemberi pelayanan terhadap yang mendapatkan pelayanan harus diwujudkan dalam lima hal yaitu:

a.

Mampu memberikan perhatian terhadap berbagai bentuk pelayanan yang diberikan, sehingga yang dilayani merasa menjadi orang yang penting.

b. Mampu memberikan keseriusan atas aktivitas kerja pelayanan yang diberikan, sehingga yang dilayani mempunyai kesan bahwa pemberi pelayanan menyikapi pelayanan yang diinginkan.

c.

Mampu menunjukan rasa simpatik atas pelayanan yang diberikan, sehingga yang dilayani merasa memiliki wibawa atas pelayanan yang dilakukan.

d.

Mampu menunjukkan pengertian yang mendalam atas berbagai hal yang diungkapkan, sehingga yang dilayani menjadi lega dalam menghadapi bentuk-bentuk pelayanan yang dirasakan.

e.

Mampu menunjukkan keterlibatannya dalam memberikan pelayanan atas berbagai hal yang dilakukan, sehingga yang dilayani menjadi tertolong menghadapi berbagai bentuk kesulitan pelayanan.

Bentuk-bentuk pelayanan ini menjadi suatu yang banyak dikembangkan oleh para pengembang organisasi, khususnya bagi pengembang pelayanan modern, yang bertujuan memberikan kualitas layanan yang sesuai dengan dimensi empati atas berbagai bentuk-bentuk permasalahan pelayanan yang dihadapi oleh yang membutuhkan pelayanan, sehingga dengan dimensi empati 
ini, seorang pegawai menunjukkan kualitas layanan sesuai dengan prestasi kerja yang ditunjukkan.

\section{Kehandalan (Reliability)}

Menurut Tjiptono (2006:70), keandalan (reliability) merupakan kemampuan memberikan layanan yang dijanjikan dengan segera, akurat dan memuaskan. Hal ini berarti perusahaan memberikan jasanya secara tepat semenjak saat pertama (right the first time). Selain itu juga berarti bahwa perusahaan yang bersangkutan memenuhi janjinya, misalnya menyampaikan jasanya sesuai dengan jadwal yang disepakati.

Kaitan dimensi pelayanan reliability (kehandalan) merupakan suatu yang sangat penting dalam dinamika kerja suatu organisasi. Kehandalan merupakan bentuk ciri khas atau karakteristik dari pegawai yang memiliki prestasi kerja tinggi. Kehandalan dalam pemberian pelayanan dapat terlihat dari kehandalan memberikan pelayanan sesuai dengan tingkat pengetahuan yang dimiliki, kehandalan dalam terampil menguasai bidang kerja yang diterapkan, kehandalan dalam penguasaan bidang kerja sesuai pengalaman kerja yang ditunjukkan dan kehandalan menggunakan teknologi kerja. Sunyoto (2004:16) kehandalan dari suatu individu organisasi dalam memberikan pelayanan sangat diperlukan untuk menghadapi gerak dinamika kerja yang terus bergulir menuntut kualitas layanan yang tinggi sesuai kehandalan individu pegawai. Kehandalan dari seorang pegawai yang berprestasi, dapat dilihat dari:

a. Kehandalan dalam memberikan pelayanan yang sesuai dengan tingkat pengetahuan terhadap uraian kerjanya.

b. Kehandalan dalam memberikan pelayanan yang terampil sesuai dengan tingkat keterampilan kerja yang dimilikinya dalam menjalankan aktivitas pelayanan yang efisien dan efektif.

c. Kehandalan dalam memberikan pelayanan yang sesuai dengan pengalaman kerja yang dimilikinya, sehingga penguasaan tentang uraian kerja dapat dilakukan secara cepat, tepat, mudah dan berkualitas sesuai pengalamannya.

d. Kehandalan dalam mengaplikasikan penguasaan teknologi untuk memperoleh pelayanan yang akurat dan memuaskan sesuai hasil output penggunaan teknologi yang ditunjukkan.

Berdasarkan uraian tersebut di atas, maka dapat dipahami bahwa kualitas layanan dari kehandalan dalam suatu organisasi dapat ditunjukkan kehandalan pemberi pelayanan sesuai dengan bentuk-bentuk karakteristik yang dimiliki oleh pegawai tersebut, sesuai dengan keberadaan organisasi tersebut. Seorang pegawai dapat handal apabila tingkat pengetahuannya digunakan dengan baik dalam memberikan pelayanan yang handal, kemampuan keterampilan yang dimilikinya diterapkan sesuai dengan penguasaan bakat yang terampil, pengalaman kerja mendukung setiap pegawai untuk melaksanakan aktivitas kerjanya secara handal dan penggunaan teknologi menjadi syarat dari setiap pegawai yang handal untuk melakukan berbagai bentuk kreasi kerja untuk memecahkan berbagai permasalahan kerja yang dihadapinya secara handal.

\section{Definisi Kepuasan Pelanggan}

Dari keseluruhan kegiatan yang dilakukan oleh sebuah perusahaan pada akhirnya akan bermuara pada nilai yang akan diberikan oleh pelanggan mengenai kepuasan yang dirasakan. Kepuasan merupakan tingkat perasaan dimana seseorang menyatakan hasil perbandingan atas kinerja produk (jasa) yang diterima dan diharapkan (Lupiyoadi dan Hamdani, 2008:192).

Dalam konteks pelanggan umumnya harapan konsumen merupakan 
perkiraan atau keyakinan pelanggan tentang apa yang akan diterimanya. Harapan pelanggan diyakini mempunyai peranan besar dalam menentukan kualitas jasa dan kepuasan pelanggan. Pada dasarnya ada hubungan yang erat antara penentuan kualitas dan kepuasan pelanggan. Dalam mengevaluasi, pelanggan akan menggunakan harapannya sebagai standar atau acuan (Fandy Tjiptono, 2006:160).

Kotler dan Keller (2007:177), menyatakan bahwa kepuasan adalah perasaan senang atau kecewa seseorang yang muncul setelah membandingan kinerja (atau hasil) produk yang dipikirkan terhadap kinerja (atau hasil) yang diharapan. Dengan kata lain, seseorang merasa puas apabila hasil yang didapat minimal mampu memenuhi harapannya sedangkan seseorang merasa tidak puas apabila hasil yang didapat tidak mampu memenuhi harapannya.

Pada dasarnya kepuasan dan ketidakpuasan pelanggan atas produk atau jasa akan berpengaruh pada pola perilaku selanjutnya. Apabila pelanggan merasa puas, maka dia akan menunjukkan besarnya kemungkinan untuk kembali menggunakan produk atau jasa yang sama. Pelanggan yang puas juga cenderung akan memberikan referensi yang baik terhadap produk atau jasa kepada orang lain (Lupiyoadi dan Hamdani, 2006:194). Tidak demikian dengan pelanggan yang tidak puas. Ketidakpuasan pelanggan bisa menimbulkan sikap negatif terhadap merek maupun produsen atau penyedia jasanya bahkan bisa pula distributornya, berkurangnya kemungkinan pembelian ulang, peralihan merek, dan berbagai macam perilaku komplain (Tjiptono, 2007:352). Realisasi kepuasan pelanggan sangat penting dilakukan perusahaan karena seorang pelanggan yang tidak puas dapat merusak citra perusahaan.

Pengukuran kepuasan pelanggan perlu dilakukan oleh perusahaan untuk mengetahui kinerja perusahaan menurut sudut pandang konsumen. Menurut Fornel dalam Tjiptono (2007:365), meskipun belum ada konsensus mengenai cara mengukur kepuasan pelanggan, sejumlah studi menunjukan bahwa ada tiga aspek penting yang perlu ditelaah dalam kerangka pengukuran kepuasan pelanggan, yaitu:

1. Kepuasan general atau keseluruhan (overall satisfaction)

2. Konfirmasi harapan (confirmation of expectations), yakni tingkat kesesuaian antara kinerja dengan ekspektasi

3. Perbandingan dengan situasi ideal (comparison to ideal), yaitu kinerja produk dibandingkan dengan produk ideal menurut persepsi konsumen

Kotler dalam Tjiptono (2007:367) menyatakan ada empat metode yang banyak digunakan dalam pengukuran kepuasan pelanggan, yaitu:

1. Sistem keluhan dan saran

Setiap organisasi yang berorientasi pada pelanggan wajib memberikan kesempatan yang seluas-luasnya bagi para pelanggannya untuk menyampaikan saran, kritik, pendapat, dan keluhan mereka.

2. Ghost Shopping

Salah satu metode untuk memperoleh gambaran mengenai kepuasan pelanggan adalah dengan mempekerjakan beberapa orang ghost shoppers untuk berperan sebagai pelanggan potensial jasa perusahaan dan pesaing. Mereka diminta melaporkan berbagai temuan penting berdasarkan pengalamannya mengenai kekuatan dan kelemahan jasa perusahaan dibandingkan para pesaing. Selain itu para ghost shoppers juga dapat mengobservasi cara perusahaan dan pesaingnya melayani permintaan spesifik pelanggan, menjawab pertanyaan pelanggan, dan menangani setiap masalah atau keluhan pelanggan

3. Lost costumer analysis

Perusahaan seyogyanya menghubungi para pelanggan yang telah berhenti membeli atau yang telah beralih pemasok agar dapat memahami mengapa hal itu terjadi dan supaya dapat mengambil kebijakan perbaikan/ 
penyempurnaan selanjutnya.

4. Survei kepuasan pelanggan

Umumnya sebagian besar penelitian mengenai kepuasan pelanggan menggunakan metode survei, baik via pos, telepon, e-mail, maupun wawancara langsung. Melalui survei, perusahaan akan memperoleh tanggapan dan umpan balik langsung dari pelanggan dan juga memberikan sinyal positif bahwa perusahaan menaruh perhatian terhadap mereka

Faktor-faktor yang mempengaruhi kepuasan dan ekspektasi pelanggan menurut Gaspersz (2003:35) terdiri dari:

1. Kebutuhan dan keinginan" yang berkaitan dengan hal-hal yang dirasakan pelanggan ketika ia sedang mencoba melakukan transaksi dengan produsen jasa. Jika pada saat itu kebutuhan dan keinginannya besar, harapan atau ekspektasi pelanggan akan tinggi, demikian pula sebaliknya.

2. Pengalaman masa lalu (terdahulu) ketika menggunakan jasa pelayanan dari organisasi jasa maupun pesaing-pesaingnya.

3. Pengalaman dari teman-teman, yang menceritakan mengenai kualitas layanan jasa yang dirasakan oleh pelanggan itu. Hal ini jelas mempengaruhi persepsi pelanggan terutama pada jasa-jasa yang dirasakan berisiko tinggi.

4. Komunikasi melalui iklan dan pemasaran juga mempengaruhi pelanggan. Orang-orang di bagian penjualan dan periklanan seyogyanya tidak membuat kampanye yang berlebihan melewati tingkat ekspektasi pelanggan. Kampanye yang berlebihan dan secara aktual tidak mampu memenuhi ekspektasi pelanggan akan mengakibatkan dampak negatif terhadap persepsi pelanggan tentang pelayanan jasa yang diberikan.

Penyelenggaraan suatu pelayanan, baik kepada pelanggan internal maupun eksternal, pihak penyedia dan pemberi pelayanan harus selalu berupaya untuk mengacu kepada tujuan utama pelayanan yaitu kepuasan pelanggan (consumer satisfaction) atau kepuasan pelanggan (customer satisfaction).

Tingkat kepuasan yang diperoleh para pelanggan biasanya sangat berkaitan erat dengan standar kualitas barang atau jasa yang dinikmati serta layanan lain berupa layanan pra-jual, saat transaksi dan purna jual. Ukuran standar kualitas yang ditentukan oleh produsen barang atau jasa belum tentu sama dengan ukuran standar kualitas yang ditentukan oleh pelanggan. Misalnya, apabila dalam memberikan pelayanan yang sama kepada pelanggan yang berbeda, maka tingkat kepuasan yang dirasakan oleh masing-masing pelanggan akan berbeda. Dalam hal ini, tentu saja pernyataan pelanggan akan sangat beragam, tergantung citarasa yang bersangkutan.

Sebagai pihak yang melayani hanya akan tahu tingkat kepuasan masingmasing pelanggan dari pernyataan pelanggan yang bersangkutan. Dalam hal ini, tentu saja sifatnya subyektif dan kita tidak akan pernah tahu secara pasti apakah pernyataan dari pelanggan itu benar-benar tulus atau hanya sekedar basa-basi.

\section{Kerangka Analisis}
Pelayanan :
a. Tangibles
b. Reliability
c. Responsiveness
d. Assurance
e. empathy

Kepuasan Pelanggan

Gambar 1. Kerangka Analisis 


\section{HASIL PENELITIAN DAN PEMBAHASAN Karakteristik Responden}

Responden penelitian ini adalah pelanggan bengkel Candera Motor Kaur yang sudah menjadi langganan minimal satu kali yang berjumlah 60 orang. Berikut ini merupakan komposisi responden menurut karakteristiknya.

Tabel 2. Karakteristik Responden di bengkel Candera Motor Kaur

\begin{tabular}{|c|c|c|c|}
\hline No & Karakteristik & Responden & Persentase \\
\hline 1 & $\begin{array}{l}\text { Jenis kelamin } \\
\text { a. Laki-laki } \\
\text { b. Perempuan }\end{array}$ & $\begin{array}{l}49 \\
11\end{array}$ & $\begin{array}{l}82 \% \\
18 \%\end{array}$ \\
\hline & Jumlah & 60 & $100 \%$ \\
\hline 2 & $\begin{array}{l}\text { Lama jadi langganan } \\
\text { a. } \quad 1-3 \text { tahun } \\
\text { b. } \quad 4-6 \text { tahun } \\
\text { c. } \quad 7-10 \text { tahun }\end{array}$ & $\begin{array}{c}39 \\
13 \\
8\end{array}$ & $\begin{array}{l}65 \% \\
22 \% \\
13 \%\end{array}$ \\
\hline & Jumlah & 60 & $100 \%$ \\
\hline 3 & $\begin{array}{l}\text { Usia } \\
\text { a. } \quad<25 \text { tahun } \\
\text { b. } \quad 25-35 \text { tahun } \\
\text { c. } \quad 35-45 \text { tahun } \\
\text { d. } \quad>45 \text { tahun }\end{array}$ & $\begin{array}{c}14 \\
23 \\
19 \\
4\end{array}$ & $\begin{array}{l}21 \% \\
42 \% \\
26 \% \\
11 \%\end{array}$ \\
\hline & Jumlah & 60 & $100 \%$ \\
\hline
\end{tabular}

Sumber: Penelitian 2013

Berdasarkan tabel 2 diatas diketahui bahwa pelanggan pada bengkel Candera Motor Kaur di dominasi oleh pelanggan laki-laki. Terlihat dari hasil kuesioner pelanggan laki-laki berjumlah 49 orang atau sebesar $82 \%$ sedangkan pelanggan perempuan berjumlah 11 orang atau sebesar $18 \%$. Hal ini menggambarkan pelanggan dari bengkel Candera Motor mayoritas laki-laki karena pada saat menunggu kendaraan selesai di service ruang tunggu pada bengkel Candera Motor terasa kurang nyaman bagi perempuan.

Kemudian jika dilihat dari segi lamanya menjadi langganan dari bengkel Candera Motor Kaur didominasi oleh 1-3 tahun atau $65 \%$ dari total pelanggan yang ada. Urutan kedua ditempati oleh 4-6 tahun dan selebihnya adalah 7-10 tahun sebesar 13\%. Kondisi ini menggambarkan bahwa dari tahun ke tahun pelanggan dari bengkel Candera Motor Kaur semakin meningkat. Semua ini terlaksana karena adanya pelayanan yang bagus dari bengkel Candera Motor Kaur yang selalu menarik para pelanggannya untuk datang melakukan service kendaraan mereka pada bengkel Candera Motor Kaur.

Karakteristik responden dilihat dari segi usia, kebanyakan usia para pelanggan berusia 25 sampai 35 tahun sebanyak 23 orang atau sebesar $42 \%$, sedangkan pada urutan kedua adalah berusia 35 sampai 45 tahun. Jumlah terkecil sebesar $11 \%$ atau 4 orang pelanggan berusia diatas 45 tahun.

\section{Pengujian Hipotesis}

Untuk menganalisa hubungan pelayanan dengan kepuasan pelanggan pada bengkel Candera Motor Kaur dianalisa dengan Korelasi rank spearman dengan rumus :

$$
\rho=1-\frac{6 \sum b i^{2}}{n\left(n^{2}-1\right)}
$$


Berdasarkan lampiran 4 tabel perengkingan pelayanan dengan kepuasan pelanggan dapat diketahui :

$$
\begin{array}{lc}
\mathrm{n}= & 60 \\
\sum \mathrm{bi}^{2}= & 10.768,50
\end{array}
$$

Apabila hasil penentuan ranking dari semua jawaban responden dimasukkan dalam rumus korelasi rank spearman, maka hasilnya akan dapat diketahui sebagai berikut :

$$
\begin{aligned}
& \rho=1-\frac{6(10.768,50)}{60\left(60^{2}-1\right)} \\
& \rho=1-\frac{64.611}{60(3.600-1)} \\
& \rho=1-\frac{64.611}{60(3.599)} \\
& \rho=1-\frac{64.611}{215.940} \\
& \rho=1-0,299 \\
& \rho=0,701
\end{aligned}
$$

Diketahui bahwa besar korelasi antara hubungan pelayanan dengan kepuasan pelanggan bengkel Candera Motor di Kaur Kabupaten Kaur adalah sebesar 0,701.

Keterangan :

$$
\begin{aligned}
& 0,00-0,19=\text { Sangat Lemah } \\
& 0,20-0,39=\text { Lemah } \\
& 0,40-0,59=\text { Sedang } \\
& 0,60-0,79=\text { Kuat } \\
& 0,80-1,00=\text { Sangat Kuat }
\end{aligned}
$$

(Sumber : Sugiyono 2013 : 184)

Artinya antara pelayanan dengan kepuasan pelanggan bengkel Candera Motor di Kaur Kabupaten Kaur memiliki korelasi yang kuat karena angka 0,701 terletak diantara angka 0,60-0,79. Hal ini menunjukkan bahwa terdapat korelasi yang kuat pelayanan dengan kepuasan pelanggan bengkel Candera Motor di Kaur Kabupaten Kaur. Ini berarti bahwa semakin tinggi pelayanan yang diberikan oleh bengkel Candera Motor Kaur maka akan semakin tinggi pula tingkat kepuasan dari para pelanggan bengkel Candera Motor Kaur. Dengan adanya pelayanan yang baik dari bengkel Candera Motor Kaur baik dari segi kerapian karyawan, cepat tanggap dalam melayani keluhan dari para pelanggan, selalu sopan santun dalam berbicara serta menerima keluhan dari para pelanggan maka akan semakin meningkatkan kepercayaan dari para pelanggan untuk selalu melakukan service kendaraan mereka di bengkel Candera Motor Kaur.

Untuk menguji tingkat signifikansi korelasi rank spearman, maka dilakukan uji hipotesis statistik. Rumus yang digunakan untuk menguji hipotesis statistik dalam penelitian tentang hubungan layanan dengan kepuasan pelanggan bengkel Candera Motor Kaur adalah uji t' maka dapat diketahui :

$$
\rho=0,701
$$




$$
\begin{aligned}
& \mathrm{n}=60 \\
& \text { Rumus untuk uji } \mathrm{t}_{\text {hitung }} \text { adalah sebagai berikut } \\
& \begin{array}{l}
t=r \sqrt{\frac{n-2}{1-r^{2}}} \\
t=0,701 \sqrt{\frac{60-2}{1-0,701^{2}}} \\
t=0,701 \sqrt{\frac{58}{1-0,491}} \\
t=0,701 \frac{7,616}{0,713} \\
t=0,701(10,676) \\
t=7,482
\end{array}
\end{aligned}
$$

Dari Hasil Uji hipotesis diperoleh nilai $t_{\text {hitung }}$ adalah 7,482 kemudian dibandingkan dengan dengan nilai $t_{\text {tabel }}$ dengan level of signifikan ditetapkan $95 \%$ dengan perhitungan satu arah dan $\mathrm{dk}=\mathrm{n}-2=60-2=58$, maka diketahui nilai $t_{\text {tabel }}$ sebesar 1,672 dengan kriteria :

H0: Pelayanan tidak mempunyai hubungan yang signifikan dengan kepuasan pelanggan bengkel Candera Motor di Kaur Kabupaten Kaur

$\mathrm{Ha}$ : Pelayanan mempunyai hubungan yang signifikan dengan kepuasan pelanggan bengkel Candera Motor di Kaur Kabupaten Kaur

Hasil uji hipotesis diketahui bahwa $t_{\text {hitung }}$ lebih besar dari $t_{\text {tabel }}(7,482>1,672)$. Dengan demikian hasil hipotesis adalah $\mathrm{HO}$ ditolak dan $\mathrm{Ha}$ diterima. artinya pelayanan mempunyai hubungan yang signifikan dengan kepuasan pelanggan bengkel Candera Motor di Kaur Kabupaten Kaur.

\section{Pembahasan}

Secara umum penelitian ini menunjukkan hasil yang cukup memuaskan. Hasil analisis deskriptif menunjukkan bahwa kualitas pelayanan yang diberikan oleh bengek Candera Motor secara umum sudah baik. Hal ini dapat ditunjukkan dari banyaknya tanggapan kepuasan yang tinggi dari responden terhadap kondisi dari masing-masing variabel penelitian. Dari hasil tersebut selanjutnya diperoleh bahwa variabel kualitas pelayanan dalam kelima dimensinya memiliki pengaruh yang positif dan signifikan terhadap kepuasan pelanggan.

Hasil penelitian korelasi rank spearman memiliki korelasi sebesar 0,701 Artinya antara pelayanan dengan kepuasan pelanggan bengkel Candera Motor di Kaur Kabupaten Kaur memiliki korelasi yang kuat hal ini menunjukkan bahwa terdapat korelasi yang kuat pelayanan dengan kepuasan pelanggan bengkel Candera Motor di Kaur Kabupaten Kaur. Ini berarti bahwa semakin tinggi pelayanan yang diberikan oleh bengkel Candera Motor Kaur maka akan semakin tinggi pula tingkat kepuasan dari para pelanggan bengkel Candera Motor Kaur

Hal ini diperkuat dengan hasil hipotesis yang membuktikan bahwa $t_{\text {hitung }}$ lebih besar dari tabel $(7,482>1,672)$. Dengan demikian hasil hipotesis adalah $\mathrm{HO}$ ditolak dan $\mathrm{Ha}$ diterima. artinya pelayanan mempunyai hubungan yang signifikan dengan kepuasan pelanggan bengkel Candera Motor di Kaur Kabupaten Kaur. 
Oleh karena itu, masyarakat sebagai pengguna jasa kini semakin selektif dalam memilih bengkel untuk melakukan perbaikan kendaraan yang dimilikinya. Bisnis perbengkelan merupakan bisnis jasa yang berdasarkan pada azas kepercayaan yang didasarkan pada kualitas pelayanan yang diberikan sehingga masalah kualitas layanan menjadi faktor yang sangat menentukan keberhasilan bisnis perbengkelan.

Lebih jauh kualitas layanan adalah upaya pemenuhan kebutuhan dan keinginan pelanggan serta ketepatan penyampaiannya untuk mengimbangi harapan pelanggan (Tjiptono, 2006:48). Dari hasil penelitian, hal ini telah dibuktikan oleh bengkel Candera Motor melalui upaya memuaskan harapan pelanggan dengan pemberian pelayanan yang berkualitas. Hasilnya memperlihatkan bahwa kualitas pelayanan yang baik berpengaruh kuat terhadap pembentukan kepuasan pelanggan.

Berdasarkan hasil penelitian ini, terdapat dan terbukti adanya pengaruh positif dari kualitas pelayanan terhadap kepuasan pelanggan pada bengkel Candera Motor Kaur. Hal ini dibuktikan dengan adanya kepuasan pelanggan terhadap pelayanan yang diberikan oleh bengkel Candera Motor Kaur baik dalam kehandalan dan kecepatan pelayanan yang diberikan oleh karyawan bengkel Candera Motor Kaur, maupun kesopanan dan ramah tamah dari para karyawan dalam memberikan pelayanan.

Hasil penelitian ini membuktikan bahwa pelanggan pada suatu bengkel tidak hanya ingin memperbaiki kendaraan yang mereka miliki di bengkel tersebut tetapi juga memperhatikan pelayanan yang diberikan oleh pihak bengkel. Pelayanan yang maksimal dari karyawan bengkel Candera Motor akan dapat menambah kenyamanan dan ketentraman para pelanggan dalam melakukan service pada bengkel Candera Motor. Oleh karena itu peningkatan kualitas pelayanan yang semakin baik perlu dilakukan oleh pihak bengkel dari waktu ke waktu. Hal ini dikarenakan sifat pelanggan yang dinamis dan cenderung selalu ingin mendapakan sesuatu yang berbeda. Tentunya perbedaan tersebut mengarah kepada sesuatu yang baik dan memiliki nilai (value) tertentu bagi pelanggan.

Assauri (2003:78) menyatakan para pelanggan akan mencari produk berupa barang atau jasa dari perusahaan yang dapat memberikan pelayanan yang terbaik kepadanya. Pelayanan merupakan inti kelangsungan hidup sebuah perusahaan, persaingan yang semakin ketat akhir-akhir ini menuntut sebuah lembaga penyedia jasa/layanan untuk selalu memanjakan konsumen/pelanggan dengan memberikan pelayanan terbaik. Pelayanan merupakan komponen penting dalam persepsi pelanggan, juga sangat penting dalam pengaruhnya terhadap kepuasan pelanggan. Semakin baik kualitas maka jasa yang diberikan maka akan semakin baik pula citra jasa tersebut dimata pelanggan.

Tjiptono, (2006:65) mengemukakan pada dasarnya ada hubungan yang erat antara penentuan kualitas pelayanan dan kepuasan pelanggan dalam mengevaluasi hal ini pelanggan akan menggunakan harapannya sebagai standar atau acuan. Harapan pelanggan berkembang dari waktu ke waktu seiring dengan semakin banyaknya informasi yang diterima serta makin bertambahnya pengalamannya. Pada gilirannya semua ini akan berpengaruh terhadap tingkat kepuasan yang dirasakan pelanggan.

\section{Kesimpulan}

Berdasarkan hasil penelitian berkenan dengan pengaruh kualitas pelayanan terhadap kepuasan pelanggan pada bengel Candera Motor Kaur dapat disimpulkan sebagai berikut:

1. Hasil penelitian korelasi rank spearman memiliki korelasi sebesar 0,701 artinya antara pelayanan dengan kepuasan pelanggan bengkel Candera Motor 
di Kaur Kabupaten Kaur memiliki korelasi yang kuat hal ini menunjukkan bahwa terdapat korelasi yang kuat pelayanan dengan kepuasan pelanggan bengkel Candera Motor di Kaur Kabupaten Kaur. Ini berarti bahwa semakin tinggi pelayanan yang diberikan oleh bengkel Candera Motor Kaur maka akan semakin tinggi pula tingkat kepuasan dari para pelanggan bengkel Candera Motor Kaur

2. Hasil pengujian hipotesis membuktikan bahwa $t_{\text {hitung }}$ lebih besar dari $t_{\text {tabel }}$ $(7,482>1,672)$. Dengan demikian hasil hipotesis adalah HO ditolak dan $\mathrm{Ha}$ diterima. artinya pelayanan mempunyai hubungan yang signifikan dengan kepuasan pelanggan bengkel Candera Motor di Kaur Kabupaten Kaur.

\section{Saran}

Berdasarkan hasil penelitian yang dilakukan dapat dikemukakan saran sebagai berikut :

1. Kehandalan karyawan dalam melayani pelanggan dirasa sudah cukup baik karena pelayanan selalu dilakukan dengan cepat, namun masih adanya keterbatasan pengetahuan dari mekanik di dalam memperbaiki kendaraan

2. Pemberian pelatihan sangat perlu dilakukan oleh bengkel Candera Motor terhadap para mekaniknya atau menambah karyawan pada posisi mekanik dengan catatan mekanik yang dicari sudah berpengalaman dan berpengetahuan yang tinggi.

3. Menyediakan ruang tunggu yang nyaman sehingga para pelanggan merasa nyaman pada waktu menunggu kendaraan mereka di service.

\section{DAFTAR PUSTAKA}

Assauri, Sofjan. 2003. "Customer Service yang Baik Landasan Pencapaian Customer Satisfaction" dalam Usahawan, No. 01, Tahun XXXII, Januari, Jakarta

Arisutha, Damartaji, 2005. Dimensi Kualitas Pelayanan. Penerbit Gramedia Pustaka, Jakarta.

Bagus, Tri Laksono, 2009, Analisis Pengaruh Kualitas Pelayanan Terhadap Kepuasan Nasabah (Studi Kasus pada Bank Jateng Cabang Utama Semarang) Skripsi.

Cristhoper H Lovelock dan Lauren K. Wright, 2005, Manajemen Pemasaran Jasa, Alih bahasa Agus Widyantoro, Cetakan Kedua, Jakarta; PT.INDEKS.

Farah Margaretha, 2003. Teori Dan Aplikasi Manajemen Keuangan Investasi dan Sumber Dana Jangka Pendek. Jakarta : Grasindo Gramedia Widiasarana Indonesia

Gaspersz, Vincent, 2003. Sistem Manajemen Kinerja Terintegrasi, Balanced corecard dan Six Sigma untuk Organisasi Bisnis dan Pemerintahan, PT Gramedia Pustaka Utama, Jakarta

Kotler, Philip., dan Armstrong, Gary. 2008. Principles Of Marketing, International Edition. Jilid 12. Prentice Hall, London.

Lupiyoadi Rambat, et al, 2008, Manajemen Pemasaran Jasa. PT. Salemba Empat, Jakarta. 
., Hamdani, A, 2006. Manajemen Pemasaran Jasa Jakarta: Salemba Empat

Hamdani, A.2007. Manajemen Pemasaran Jasa (Edisi 2). Jakarta: Salemba Empat

Philip Kotler \& Kevin Lane Keller,2009, Manajemen pemasaran ,Edisi 13 Jilid 1. Jakarta , 2007, Marketing Management, Pearson Prentice Hall, New . v. .

Stemvelt, Robert C., 2004. (Diterjemahkan oleh Purwoko) Perception of Service Quality. Allyn and Bacon, Massachusetts.

Sugiyono, 2013. Metode penelitian pendidikan: pendekatn kuantitatif, kualitatif, dan $R \& D$. Bandung: Alfabeta , 2013. Statistika untuk Penelitian. Bandung: Alfabeta

Tjiptono, Fandy, 2006,Manajemen Pelayanan Jasa, Penerbit Andi, Yogyakarta Jakarta.

2007. Kepuasan dalam Pelayanan. Penerbit Salemba Empat,

Yong, C.Z., Yun, Y.W., Loh, L., 2003. (Diterjemahkan oleh Sutanto). The Quest for Global Quality. Pustaka Delapratasa, Jakarta. 